\title{
HUBUNGAN TINGKAT PENGETAHUAN DENGAN MOTIVASI MELAKUKAN IVA TEST PADA IBU RUMAH TANGGA DI DESA SAKUNG KECAMATAN DELANGGU KABUPATEN KLATEN
}

\author{
Sri Aminingsih ${ }^{1}$, Marta Putri Budiningtyas ${ }^{2}$
}

\begin{abstract}
Abstrak
Background. Interviews conducted five housewife in the village Sakung regarding the level of knowledge about cervical cancer, showed 2 of 5 housewife in the village Sakung know about cervical cancer, while 3 Housewives do not know well about cervical cancer and even some mothers did not know about cervical cancer and examination of IVA Test as early detection of cervical cancer, there are some mothers who want to do the IVA Test but in the nearest health center are no programs for the examination of IVA Test. According to Purnomo (2009) for a positive thing, especially for the future of reproductive health should conduct checks as early as possible so that its impact can be quickly resolved

Objective: To determine the relationship of the level of knowledge about cervical cancer with the motivation of doing IVA Test on a housewife in the village Sakung Delanggu District of Klaten District.

Methods: This study was a cross sectional study design measurements or observations made simultaneously at any one time (one time). Number of samples of this study 86 housewife.

Results: The results of chi-square analysis using SPSS version 18.0 with $p=$ $0.05 p=0,000$ is obtained so that the value of $p<0.05$, which means Haaccepted. Conclusion: There is a relationship with the motivation level of knowledge did IVA Test housewives in the village Sakung Delanggu District Subdistrict Klaten. with $p=0.000$.
\end{abstract}

Keywords: The level of knowledge, motivation did IVA Test, Cervical Cancer

\section{PENDAHULUAN}

Kanker serviks cenderung muncul pada perempuan berusia 35 sampai dengan 55 tahun. Data yang di dapat dari yayasan kanker Indonesia tahun 2007 menyebutkan setiap tahunnya sekitar 500.000 perempuan didiagnosa menderita kanker serviks dan lebih dari 250.000 meninggal dunia. Total 2,2 juta perempuan di dunia menderita kanker serviks. Beberapa data lain menyebutkan kanker serviks juga dapat muncul pada perempuan dengan usia yang relatif muda. Di Indonesia sendiri diperkirakan setiap harinya terjadi 41 kasus baru kanker serviks dan 20 perempuan meninggal dunia karena penyakit tersebut. (Purnomo, 2009)

Kanker serviks, sering juga disebut dengan kanker mulut rahim atau kanker leher rahim adalah kanker yang berasal dan tumbuh pada serviks atau mulut rahim, khususnya berasal dari epitel atau lapisan luar permukaan serviks dan 99,7 persen disebabkan oleh virus HVP (Human Papilloma Virus). Kanker serviks merupakan kanker terbanyak kedua setelah kanker payudara yang saat ini menyerang pada perempuan. Hal ini bisa terjadi karena saat ini perhatian masyarakat di negara maju terhadap kesehatan sangat meningkat sehingga penyakit lebih 
cepat untuk terdeteksi. Beberapa dengan masyarakat Indonesia yang mengalami pola kehidupan yang sangat memungkinkan peningkatan virus penyebab kanker serviks itu. (Samadi, 2011)

Hal terpenting yang seharusnya memahami tentang kanker serviks adalah bahwa penyakit ini berkembang dalam waktu yang relatif lama. Artinya, mulai infeksi virus sampai pada akhirnya menjadi sel kanker membutuhkan waktu 3 sampai dengan 14 tahun atau hampir rata-rata 10 tahun. Kanker serviks ini juga berkembang secara bertahap, yang fase pra kanker, yang jika ditemukan dan diobati dengan baik dapat sembuh 100\%. Ada metode deteksi dini yang cukup efektif untuk menemukan penyakit pada fase pra kanker atau kanker stadium dini yaitu dengan melakukan pap smear, IVA Test (Inspeksi Visual dengan Asam Asetat), dan koloskopi. Bahkan saat ini sudah berkembang beberapa pemeriksaan lain seperti pemeriksaan untuk mendeteksi apakah seorang perempuan terinfeksi Human Papilloma Virus (HPV) penyebab kanker serviks dengan pemeriksaan HPV(Human Papilloma Virus) DNA Test. Perkembangan terbaru yang cukup penting, yaitu sudah tersedianya vaksin untuk mencegah virus HPV yang berarti juga mencegah seorang perempuan untuk terkena kanker serviks. Oleh karena itu adanya pengembangan vaksin virus HPV (Human Papilloma Virus) dapat diharapkan perkembangan kanker ini dapat dikendalikan, yang terutama di negara yang masih sulit melaksanakan program scrining. (Samadi, 2011)

Dari hasil wawancara terhadap 5 lbu rumah tangga di Desa Sakung mengenai tingkat pengetahuan tentang kanker serviks, didapatkan hasil 2 dari 5 lbu rumah tangga di Desa Sakung mengetahui tentang kanker serviks, sedangkan 3 lbu rumah tangga tidak mengetahui dengan baik tentang kanker serviks bahkan ada ibu yang sama sekali tidak mengetahui tentang kanker serviks dan pemeriksaan IVA Test sebagai deteksi dini untuk kanker serviks, ada beberapa lbu yang ingin melakukan IVA Test tetapi di puskesmas terdekat belum ada program untuk pemeriksaan IVA Test tersebut. Menurut Purnomo (2009) untuk suatu hal yang positif, terutama untuk masa depan kesehatan reproduksi hendaknya melakukan pemeriksaan sedini mungkin agar dampaknya dapat secara cepat diatasi.

\section{TUJUAN}

a. Mengidentifikasi tingkat pengetahuan tentang kanker serviks pada lbu rumah tangga di Desa Sakung.

b. Mengidentifikasi motivasi melakukan IVA Test pada Ibu rumah tangga di Desa Sakung.

c. Menganalisis hubungan antara pengetahuan tentang kanker serviks dengan motivasi melakukan IVA Test pada lbu rumah tangga di Desa Sakung.

\section{DESAIN PENELITIAN}

Penelitian ini merupakan penelitian analitik observasional dengan menggunakan desain crosssectional, yaitu rancangan penelitian yang pengukuran atau pengamatannya dilakukan secara simultan pada suatu saat (sekali waktu).

\section{POPULASI, SAMPEL DAN TEHNIK SAMPLING}

Dalam penelitian ini populasinya adalah ibu rumah tangga yang diambil menggunakan tabel krecjie. Dari populasi sebanyak 113 dan diperoleh sampel sebesar $86 \mathrm{lbu}$ rumah tangga. 
Dalam penelitian ini, peneliti menggunakan teknik probability sampling dengan cara simple random sampling yaitu pengambilan sampel dengan dengan cara acak tanpa memperhatikan strata yang ada dalam anggota populasi.

Tingkat kepercayaan untuk penelitian ini adalah $\mathrm{p}=0,05$ atau $5 \%$ dengan memakai rumus Chi Kuadrat artinya bahwa tingkat kepercayaan $95 \%$, atau tingkat kesalahan $5 \%$.

Penelitian ini dilakukan pada bulan September 2015 sampai Februari 2016.

\section{HASIL PENELITIAN}

Karakterisitik Responden

Tabel 1

Karakterisitik Usia Responden

\begin{tabular}{ccc}
\hline Kategori & $\mathrm{f}$ & $\%$ \\
\hline Jumlah Responden & 86 & 100 \\
\hline Usia Responden & & \\
\hline $22-38$ & 33 & 38,37 \\
\hline $39-54$ & 44 & 51,16 \\
\hline $55-70$ & 9 & 10,47 \\
\hline
\end{tabular}

Dari tabel di atas diperoleh informasi bahwa usia responden dengan jumlah terbanyak adalah usia 39-54 sebanyak 44 responden $(51,16 \%)$.

Tabel 2

Karakterisitik jumlah Anak Responden

\begin{tabular}{ccc}
\hline Kategori & $f$ & $\%$ \\
\hline Jumlah Responden & 86 & 100 \\
\hline Jumlah Anak & & \\
\hline Belum punya anak & 6 & 6,98 \\
\hline $1-3$ & 71 & 82,55 \\
\hline $4-6$ & 7 & 8,14 \\
\hline $7-9$ & 2 & 2,33 \\
\hline
\end{tabular}

Dari tabel di atas diperoleh data bahwa responden terbanyak adalah responden yang mempunyai jumlah anak 1-3 sebanyak 71 responden $(82,55 \%)$.
Tabel 3

Karakterisitik Pendidikan Responden

\begin{tabular}{ccc}
\hline Kategori & $\mathrm{f}$ & $\%$ \\
\hline Jumlah Responden & 86 & 100 \\
\hline Pendidikan & & \\
\hline SD & 17 & 19,77 \\
\hline SMP & 12 & 13,95 \\
\hline SMA/SMK & 28 & 32,56 \\
\hline DIPLOMA & 18 & 20,93 \\
\hline SARJANA & 11 & 12,79 \\
\hline
\end{tabular}

Dari tabel di atas diperoleh data bahwa responden terbanyak adalah responden yang memiliki pendidikan SMA/SMK sebanyak 28 responden (32,56\%).

Tingkat Pengetahuan

Tabel 4

Tingkat Pengetahuan tentang Kanker Serviks

\begin{tabular}{ccc}
\hline Interval & $\mathrm{f}$ & $\%$ \\
\hline Jumlah Responden & 86 & 100 \\
\hline Tingkat Pengetahuan & & \\
\hline Rendah & 4 & 4,65 \\
\hline Sedang & 15 & 17,44 \\
\hline Tinggi & 67 & 77,91 \\
\hline
\end{tabular}

Dari tabel di atas dapat dicermati bahwa persentase tingkat pengetahuan tinggi menduduki jumlah terbanyak dengan frekuensi 67 responden dengan persentase $77,91 \%$.

Motivasi Melakukan IVA Test

Tabel 5

Karakterisitik Motivasi Melakukan IVA Test

\begin{tabular}{ccc}
\hline Interval & $\mathrm{f}$ & $\%$ \\
\hline Jumlah Responden & 86 & 100 \\
\hline Motivasi & & \\
\hline Rendah & 13 & 15,12 \\
\hline Sedang & 8 & 9,30 \\
Tinggi & 65 & 75,58 \\
\hline
\end{tabular}

Dari tabel di atas dapat dicermati bahwa motivasi melakukan IVA Test paling banyak adalah tinggi dengan frekuensi 65 responden $(75,58 \%)$. 


\section{PEMBAHASAN}

1. Tingkat Pendidikan

Dari hasil penelitian. dapat dicermati bahwa pada tingkat pengetahuan dengan kategori rendah berjumlah 4 responden $(4,65 \%)$, sedang berjumlah 15 responden $(17,44 \%)$ dan tinggi berjumlah 67 responden $(77,91$ $\%)$. Hal ini membuktikan bahwa pengetahuan ibu rumah tangga di desa Sakung tentang kanker serviks adalah tinggi.

Pengetahuan adalah hasil "tahu", dan ini terjadi setelah orang melakukan pengindraan terhadap suatu objek tertentu. Pengindraan terjadi melalui panca indera manusia, yakni indera penglihatan, pendengaran, penciuman, rasa dan raba. Sebagian besar pengetahuan diperoleh melalui mata dan telinga. (Fitriani, 2011) Pengetahuan atau kognitif merupakan domain yang sangat penting untuk terbentuknya tindakan seseorang (overt behavior). Karena dari pengalaman dan penelitian ternyata perilaku yang didasarkan oleh pengetahuan akan lebih langgeng daripada perilaku yang tidak didasari oleh pengetahuan. (Notoatmojo, 2011)

Menurut Wawan dan Dewi (2011), faktor-faktor yang mempengaruhi tingkat pengetahuan adalah:

a. Pendidikan

Pada umumnya makin tinggi pendidikan seseorang makin mudah menerima informasi.

b. Pekerjaan

Bekerja umumnya merupakan kegiatan yang menyita waktu. Bekerja bagi ibu-ibu akan mempunyai pengaruh terhadap kehidupan keluarga.

c. Umur

Menurut Huclok (1998), semakin cukup umur, tingkat kematangan dan kekuatan seseorang akan lebih matang dalam berfikir. Dari segi kepercayaan masyarakat seseorang yang lebih dewasa dipercaya dari orang yang belum tinggi kedewasaannya. Hal ini akan sebagai dari pengalaman dan kematangan jiwa.

d. Lingkungan

Lingkungan merupakan seluruh kondisi yang ada disekitar manusia dan pengaruhnya yang dapat mempengaruhi perkembangan dan perilaku orang atau kelompok.

e. Sosial budaya

Sistem sosial budaya yang ada pada masyarakat dapat mempengaruhi dari sikap dalam menerima informasi.

Dalam penelitian ini salah satu faktor yang mempengaruhi tingkat pengetahuan ibu rumah tangga di desa Sakung adalah responden memiliki pendidikan terakhir terbanyak adalah SMA/SMK, dengan pendidikan yang cukup seseorang mampu melakukan analisa apabila mendapatkan suatu informasi, sedangkan berdasarkan umur responden yang terbanyak adalah antara umur 39 tahun sampai 54 tahuan. Dalam usia yang cukup dewasa seseorang bisa dikatakan cukup matang dalam memutuskan suatu permasalahan yang dihadapi apalagi yang berkaitan dengan kesehatan. Adapun dari faktor lain yaitu anak yang dimiliki oleh ibu rumah tangga di desa Sakung yang terbanyak adalah 1-3.

2. Motivasi Melakukan IVA Test

Dari hasil hasil penelitian dapat dicermati bahwa prosentasi pada motivasi melakukan IVA test dengan kategori rendah berjumlah 13 responden $(15,12 \%)$, sedang berjumlah 8 
responden $(9,30 \%)$ dan tinggi berjumlah 65 responden $(75,58$ $\%)$. Hal ini membuktikan bahwa motivasi ibu rumah tangga di desa Sakung untuk melakukan IVA Test adalah tinggi.

Motivasi adalah kondisi seseorang yang mendorong untuk mencari suatu keputusan atau mencapai suatu tujuan. Merupakan suatu alasan atau dorongan yang menyebabkan seseorang berbuat sesuatu, melakukan tindakan atau bersikap tertentu. (Sobur, 2010)

Menurut Sobur (2010), faktor yang mempengaruhi motivasi adalah sebagai berikut:

a. Faktor internal:

1). Harga diri dan prestasi

Faktor ini mendorong atau mengarahkan individu untuk berusaha agar menjadi seseorang yang mandiri dan tangguh, serta mampu mendorong seorang individu untuk berprestasi.

2). Harapan

Merupakan informasi obyektif dari lingkungan yang mempengaruhi sikap dan perasaan.

3). Kebutuhan

Menjadikan dirinya sendiri berfungsi secara penuh, sehingga mampu meraih potensinya secara total.

4). Kepuasan kerja

Suatu dorongan afektif yang muncul dari dalam individu untuk mencapai tujuan yang diinginkan.

b. Faktor eksternal
1) Jenis dan sifat pekerjaan
2) Kelompok kerja dimana individu bergabung
3) Situasi lingkungan pada umumnya

4) Sistem imbalan yang diterima

Berdasarkan hasil penelitian diatas motivasi ibu rumah tangga di Desa Sakung untuk melakukan IVA Test dalam kategori motivasi tinggi, hal ini bisa disebabkan oleh faktor internal maupun eksternal. Bila seseorang telah memiliki pengetahuan yang mencukupi maka akan diikuti oleh suatu keinginan atau sikap yang positif, dalam hal ini adalah keinginan untuk melakukan IVA Test

3. Hubungan Tingkat Pendidikan dan Tingkat Pengetahuan

Dari hasil penelitian Hubungan Tingkat Pengetahuan dengan Motivasi Melakukan IVA Test diperoleh hasil uji Chi-Square program SPSS versi 18.0 dengan $\alpha=5 \%(0.05)$ diperoleh $p$ sebesar 0,000 sehingga nilai $p<0.05$, yang berarti $\mathrm{H}_{0}$ ditolak dan $\mathrm{H}_{a}$ diterima, sehingga ada hubungan tingkat pengetahuan dengan motivasi melakukan IVA Test pada ibu rumah tangga di desa Sakung Kecamatan Delanggu Kabupaten Klaten.

Menurut Sobur (2010), terdapat beberapa unsur pada tingkah laku yang membentuk lingkaran motivasi:

a. Kebutuhan

Motivasi pada dasarnya bukan hanya merupakan suatu dorongan fisik, tetapi juga orientasi kognitif elementer yang diarahkan pada pemuasan kita.

b. Tingkah laku

Dipergunakan sebagai cara atau alat agar suatu tujuan bisa tercapai. Tingkah laku pada dasarnya ditujukan untuk mencapai tujuan.

c. Tujuan

Berfungsi untuk memotivasikan tingkah laku. Tujuan juga menentukan 
seberapa aktif individu akan bertingkah laku.

Hasil dari penelitian pada ibu rumah tangga di Desa Sakung memiliki pengetahuan tinggi dan motivasi tinggi untuk melakukan IVA Test. Hal ini sesuai dengan teori diatas bahwa apabila seseorang memiliki pengetahuan yang tinggi akan memunculkan dorongan motivasi yang kuat dan akhirnya akan menghasilkan suatu perubahan perilaku atau tingkah laku yang berdasarkan dari pengetahuan yang telah dimiliki sebelumnya. Bila seseorang memiliki pengetahuan yang tinggi tentang kanker serviks maka orang tersebut pasti mempunyai keinginan untuk melakukan pencegahan agar tidak mengalami kanker serviks. Salah satu pencegahan yang harus dilakukan adalah dengan melakukan pemeriksaan IVA Test. Sebelum tidakan pemeriksaan IVA Test benarbenar dilakukan pasti orang tersebut sebelumnya telah mempunyai keinginan untuk melakukan perubahan perilaku yang awalnya hanya sekedar tahu dalam hal ini adalah memiliki pengetahuan saja tetapi selanjutnya akan ditindak lanjuti dengan suatu keinginan melakukan tindakan yaitu melakukan pemeriksaan IVA Test. Keinginan tersebut muncul dikarenakan ada tujuan yang ingin dicapai yaitu terhindar dari kanker serviks atau paling tidak bisa melakukan pencegahan terjadinya kanker serviks.

\section{KESIMPULAN}

Dari hasil penelitian yang berjudul hubungan tingkat pengetahuan dengan motivasi melakukan IVA Test didapatkan hasil sebagai berikut:
1. Responden dengan tingkat pengetahuan terbanyak adalah kategori tinggi terdapat 67 ibu rumah tangga $(77,91 \%)$.

2. Responden dengan motivasi melakukan IVA Test terbanyak adalah kategori tinggi terdapat 65 ibu rumah tangga (75,58\%).

3. Dari hasil uji Chi-Square program SPSS versi 18.0 dengan $\alpha=5 \%$ (0.05) diperoleh $p$ sebesar 0,000 sehingga nilai $p$ $<0.05$, yang berarti $\mathrm{H}_{\mathrm{o}}$ ditolak dan $\mathrm{H}_{\mathrm{a}}$ diterima, sehingga ada hubungan tingkat pengetahuan dengan motivasi melakukan IVA Test pada ibu rumah tangga di desa Sakung Kecamatan Delanggu Kabupaten Klaten.

\section{SARAN}

1. Bagi Masyarakat

Dari penelitian yang dilakukan, peneliti berharap agar masyarakat dapat memperoleh informasi yang lebih banyak tentang pemeriksaan IVA Test.

2. Bagi Dinas Pendidikan Kesehatan

Setelah melihat hasil penelitian ini, peneliti berharap agar pihak Akademi dapat mendalami bahan kajian pengajaran mata kuliah keperawatan maternitas terkait dengan pemeriksaan IVA Test.

3. Bagi Institusi Puskesmas Hasil penelitian ini diharapkan berguna sebagai bahan masukan dalam membuat kebijakan tentang reproduksi dan ginekologi.

4. Bagi Peneliti Selanjutnya Hasil penelitian ini diharapkan dapat digunakan sebagai dasar untuk menarik minat peneliti selanjutnya untuk meneliti faktor- faktor yang mempengaruhi perilaku pemeriksaan IVA Test. 
DAFTAR PUSTAKA

Hidayat, A. Aziz Alimul. 2008. Riset Keperawatan dan Teknik Penulisan IImiah. Edisi II. Salemba Medika., Jakarta.

2009. Metode Penelitian Keperawatan dan Teknik Analisa Data. Salemba Medika, Jakarta.

McCormick, Colleen dan Robert L. 2011. Giuntoli. Panduan Untuk Penderita Kanker Serviks. Alih bahasa Yuan Acitra. PT Indeks, Jakarta.

Notoatmodjo, Soekidjo. 2011. Promosi Kesehatan dan IImu Perilaku: Rineka Cipta, Jakarta.

Purnomo, Heru. 2009. Pencegahan \& Pengobatan Penyakit yang Paling Mematikan Hipertensi, Diabetes, Stroke, Kanker Payudara, Kanker Rahim, Kanker Serviks. Buana Pustaka, Yogyakarta.

Samadi, Heru Priyanto. 2011. Yes, I Know Everything about Kanker Serviks!. Cetakan I. PT Tiga Serangkai Pustaka Mandiri, Solo.

Setiati, Eni. 2009. Waspadai 4 Kanker Ganas Pembunuh Wanita. Edisi I. ANDI, Yogyakarta.
Sobur, Alex. 2010. Psikologi Umum Dalam Lintas Sejarah. Pustaka Setia, Bandung.

Suyanto. 2011. Metodologi dan Aplikasi Penelitian Keperawatan. Nuha Medika, Yogyakarta.

Wawan, A dan Dewi M. 2011. Teori dan Pengukuran Pengetahuan Sikap dan Perilaku Manusia. Nuha Medika, Yogyakarta.

Yuliatin, Indah Sri. 2011. Cegah dan Tangkal Kanker Serviks. PT Java Pustaka Grup, Surabaya.

Rakhsha, et al. 2015. "Evaluasi Kelangsungan Hidup di Karsinoma Serviks". URL: http://www.ncbi.nlm.nih.gov/ pubmed/26473640.

Fauziah, Rathi Manjari, et al. 2011. "Deteksi Dini Kanker Serviks pada Pusat Pelayanan Primer di Lima Wilayah DKI Jakarta:. URL: http//www.indonesia. digitaljournals,org/index.php /idnmed/article.

1 Dosen AKPER Panti Kosala Surakarta

2 Mahasiswa AKPER Panti Kosala Surakarta 